\title{
Understanding
}

\section{Engagement, Marketing, and Motivation to Benefit Recruitment and Retention in Citizen Science}

ADAM G. HART (D)

DAVID ADCOCK

MATTHEW BARR

STUART CHURCH (D)

TAMARA CLEGG (1)

SAMUEL COPLAND (D)
KRIS DE MEYER (D)

RIA DUNKLEY

RACHEL M. PATEMAN (D)

RALPH UNDERHILL

KAYLEIGH WYLES (D)

MICHAEL J. O. POCOCK (D)

*Author affiliations can be found in the back matter of this article

\begin{abstract}
In November 2020, a meeting was held to explore what citizen science practitioners can gain from understanding engagement, marketing, and volunteer motivations in order to benefit recruitment and retention in environmental citizen science. This report summarises the lessons learned from considering the role of people as participants within citizen science; although we note that this is only one and, for some, a contested view of participants. Marketing and motivation studies highlighted the importance of knowing more about participants. Framing and user experience experts showed how to convert knowledge into tailored approaches that enhance engagement and retention. Other fields, including the world of commerce, have potential lessons for citizen science practitioners, especially those involved in top-down, mass participatory projects that require high levels of engagement.
\end{abstract}

CITIZEN SCIENCE: THEORY AND PRACTICE

\section{] $\mathrm{u}[$ ubiquity press}

CORRESPONDING AUTHOR:

\section{Adam G. Hart}

University of Gloucestershire, GB ahart@glos.ac.uk

\section{KEYWORDS:}

engagement; motivation; participation; retention; ecology

\section{TO CITE THIS ARTICLE:}

Hart, AG, Adcock, D, Barr, M, Church, S, Clegg, T, Copland, S, De Meyer, K, Dunkley, R, Pateman, RM, Underhill, $R$, Wyles, $K$ and Pocock, MJO. 2022. Understanding Engagement, Marketing, and Motivation to Benefit Recruitment and Retention in Citizen Science. Citizen Science: Theory and Practice, 7(1): 5, pp. 1-9. DOI: https://doi. org/10.5334/cstp.436 


\section{INTRODUCTION}

The environment and biodiversity are key areas in which citizen science is well established as an invaluable tool for monitoring and research (Dickinson et al. 2012; Kullen and Kasperowski 2016). Ecological and environmental citizen science projects cover a spectrum of engagement, from small groups of highly engaged specialists, to mass participation projects aimed at members of the general public (Pocock et al. 2017; Theobald et al. 2015). One of the challenges of citizen science is that the evaluation of participant-focused outcomes of citizen science is limited (Martin 2017; Turrini et al. 2018); indeed, we often know relatively little about the characteristics and motivations of the people that engage, or do not engage, with citizen science (West and Pateman 2016).

Anecdotally, practitioners of citizen science suggest that some projects fail to achieve the level of participation required because of lack of public awareness of the project, poor uptake, poor engagement, and low retention (see also Geoghegan et al. 2016). If people do not know about projects, do not find them engaging, or do not choose to participate, then projects will fail to provide their intended benefits to individuals, to society, and to decision-makers. Of course, participants in citizen science are not customers, yet there are parallels with customer-facing sectors that already devote considerable resources to researching their base. For example, sectors such as business and marketing combine insights from customer research with established marketing theory and practice to enhance sales. For citizen science projects to achieve their goals, people need to know about the project (comparable with marketing and advertising), they need to engage with it (comparable to purchasing), and very often, it is desirable to keep them engaged (relating to customer experience, retention, and loyalty). Projects that are initiated, led, and run by people with academic scientific training (Geoghegan et al. 2016) may be strong on the science, but successful recruitment and participation depends on different skills (West and Pateman 2016). Is it useful for citizen science practitioners to consider what they can learn and apply from these customer-facing sectors.

In response to this question, a meeting was convened in November 2020 to explore current knowledge about recruitment, participation, and retention in citizen science, and to consider what we can learn from best practices in customer-facing fields. We drew on experience from experts in marketing, advertising, branding, and userexperience design, from researchers in motivational psychology and the psychology of behavioural change, and from those focusing on citizen science outcomes and engagement. Here, we report on inputs to the meeting that were delivered via presentations from speakers (the authors of this paper). The audience for this meeting was those who lead citizen science projects and who seek to improve their citizen science in terms of its reach and impact, with a particular focus on mass participation projects that seek engagement from a wide audience.

Of course, a scientist-led approach to citizen science, with people as invited contributors of data, is not the only citizen science approach; indeed, it has been subject to some criticism for its lack of inclusivity (Bonney et al. 2016; Cooper et al. 2021). Other citizen science approaches achieve their goals in more collaborative, bottom-up approaches. However, we believe that scientist-led approaches continue to have a valuable role in citizen science-for example, for cost efficient collection of large datasets via voluntary contributions from participants (Hart et al. 2018a), and for raising awareness of science and contentious or misunderstood issues (e.g., Sumner et al. 2019). Therefore, reflecting on best practice that supports success in these projects is a valuable activity for such practitioners.

\section{THE RATIONALE AND ORGANISATION OF THE MEETING}

In response to the perceived need to learn about engagement and participation from other fields (such as marketing), we (AGH, MJOP) set up a half-day seminar, run online in November 2020 and entitled Citizen Science: engagement, marketing, motivation and change. The meeting focused on citizen science projects that are initiated and run by project organisers, with a focus on data collection. These types of projects have been demonstrably impactful, both for data collection and for people's engagement with the environment (Robinson et al. 2018). The meeting was hosted by the British Ecological Society and supported by the Joint Nature Conservation Committee in the UK. More than 90 people attended from the UK, the rest of Europe, the USA, and elsewhere, which indicated the appeal of the subject. Attendees included academics, citizen science practitioners and community project leaders, with interests in ecology and the environment. Nine invited contributors (the authors) from commercial, practitioner, and academic settings presented sessions addressing the knowledge gaps identified above with the aim of improving future citizen science projects.

Attendees were encouraged to take part in the online chat that ran alongside speakers, and two breakout groups were held during the seminar. This combination of conversational channels, accentuated rather than hindered by the online environment forced upon us by COVID-19 
restrictions, resulted in a highly collegiate and collaborative atmosphere. Feedback was summed up by one attendee who commented on the final evaluation that they now saw the need to "balance 'citizen' and 'science' aspects better."

Here we provide a review of the topics addressed by speakers and the main recommendations from the meeting. This demonstrates the opportunities for improving contributory citizen science by drawing on experience from diverse fields of practice.

\section{HOW ACTIONS AFFECT BELIEFS, AND THE IMPORTANCE OF PLACE FOR IMPROVING ENGAGEMENT}

The meeting opened with a series of presentations that focused on trying to understand better why people engage with citizen science. We started by examining the idea that engagement with citizen science can spark change in participants (with respect to attitudes and behaviour) and that such change can have impacts far beyond the data collected and the project itself (Brossard et al. 2005). Citizen science can certainly provide a platform for education and for raising awareness, and the conventional wisdom is that awareness and understanding of an issue, for example, climate change, is required before individuals act (although having awareness does not necessarily lead to action; De Meyer et al. 2020). In fact, this belief-action relationship often runs in reverse in real-life scenarios: actions can affect beliefs (Albarracin and Wyer 2000). Because citizen science projects often involve action by participants, those actions can therefore influence beliefs. In ecological and environmental citizen science, therefore, there is opportunity to move from issue-based awareness raising (in the hope that action follows) toward a focus on action-based activities. Attendees indicated that they were commonly focused on developing pro-environmental behaviour and were interested in promoting the shift from issue-based education to action-based activities.

One way to enhance engagement with citizen science was explored through a presentation on the love of place, a phenomenon known as topophilia (Tuan 1974). We learned that affective connections to participants' local environments at all life stages emerged as a significant driver of participation from a qualitative study that analysed citizen science narratives (Dunkley 2017). Dunkley's work showed that many citizen science participants involved in these studies participated because they wanted to connect to a specific place that was important to them for some reason (Dunkley 2018). A relationship with a particular place can be heightened through relationships with people who share that particular topophilia. Local "Friends of..." groups can therefore play a central role in citizen science projects (e.g., the "Friends of the River Crane" group was core to the success of a project monitoring in a River Thames [UK] tributary) (Dunkley 2019). Through these discussions, it become clear that learning more about how and why people engage with a place, and the way that people with common place-related interests interact, could be valuable for developing more engaging and effective citizen science projects (Newman et al. 2017).

Place in the modern world can mean a virtual space, and the influence of the digital world and its contrast to the physical world emerged on the chat thread as a dominant theme. In the digital world, it is easy to forget that citizen science can enhance the sensory experience and the joy of the natural world that participants can feel. The sensorial qualities of citizen science were concluded to have value to participants above and beyond the value of simply taking part. Discussions concluded that even though people use environmental citizen science in different ways, for their own purposes (such as introducing school or university groups to local ecology; giving purpose to a walk in the woods; fulfilling a role as steward of a place; or trying to get to know a new place on a deeper level), the sensory experience of engaging with the natural world and the joy that it brings may be common to all or most. Overall, attendees agreed with the conclusion that participation is often an opportunity to be in commune with place and with nonhuman species, through all the senses. It is often a bodily engagement with the places where we live, and there is opportunity to develop this more strongly in some projects.

\section{PROMOTING CHANGE THROUGH ACTION AND EXPERIENCE}

Does enhanced engagement, a bodily, sensorial and emotional connection, translate to meaningful enhancement of well-being and the promotion of longlasting behavioural change in the citizen scientists? While the gold standard of citizen science argues that citizen science should benefit both the science and the citizens, benefits to citizens are often overlooked or reported only anecdotally (Robinson et al. 2018). Wyles presented preliminary findings from a before-and-after questionnaire that examined volunteers' experience of a citizen science beach cleaning event. Following the Marine Conservation Society's (MCS) beach clean protocol, volunteers selected a $100 \mathrm{~m}$ stretch of the UK coastline and then removed and recorded every item of litter they found. Just under 1,000 of the volunteers taking part also completed a questionnaire before and after the event in order to assess changes in 
well-being (did they enjoy the activity?), knowledge (did they feel more aware of marine litter?), and behaviour (will they undertake more pro-environmental behaviours afterwards?). Overall, the findings presented to the meeting indicated that volunteers enjoyed the experience, reported greater knowledge on the topic, and intended to do more afterwards (Wyles et al. unpublished data).

While these findings imply positive impacts for the volunteers, it is difficult to know why these results occurred. Was it the activity involved or was it simply spending time on the beach, which has also been shown to be beneficial (Wheeler et al. 2012; White et al. 2013), and does topophilia play a role? An experimental field study by the same team gives further insight (Wyles et al. 2017). Undergraduate students who had not participated in citizen science before (and thus had no prior expectations) were randomly allocated to one of three activities on the coast: the MCS beach clean (practical action, plus reporting the litter found); a biodiversity citizen science project (ShoreThing: recording abundance of species along the shoreline); or a coastal walk (the most common activity performed on the coast). By completing questionnaires before and after these activities, this study found that all activities were beneficial for mood and increasing general pro-environmental behaviours, but the two citizen science activities increased participants' perceptions of marine issues, and the beach clean was found to be the most meaningful activity and had the greatest impact on intentions to volunteer again in the future. The clear conclusion was that citizen will have multiple benefits to the individuals involved, by immersing themselves in a pleasant environment and by doing a meaningful and education activity.

\section{LEARNING FROM COMMERCE: KNOW YOUR MARKET}

Commercial marketing is "a social and managerial process by which individuals and organizations obtain what they need and want through creating and exchanging value with others" (Kotler 2020). In other words, marketing is about selling. Two speakers from the commercial world (Barr and Copland) led a session to explore whether lessons from commercial marketing could help improve citizen science engagement.

One key aspect of marketing is developing a greater understanding of potential customers; in the case of citizen science, these are analogous to the potential participants. We need to understand our audience, specifically, what motivates them and how can we speak to them before we can effectively "sell" to them (Osei-Frimpong 2019). This reflected earlier discussions on topophilia and the importance of understanding people's relationships with specific places. By better understanding the group of people whose contribution is sought, the chances of getting greater and more meaningful participation in projects is increased. Essentially, if barriers to participation are to be removed, we need to understand what those barriers are, to whom they are barriers, and what appropriate tools we can use to overcome them.

Attendees were asked why they thought people do not participate in citizen science research, and most responses were around the themes of time, interest, and knowledge/complexity. These are major challenges, but understanding audience motivations and values more generally might allow projects to be positioned in ways that pique the interests of potential participants (echoing the first principles of marketing strategy; Palmatier 2019). By having a greater understanding of our target audience (our "customers"), we can tweak our message (our "sales pitch") and our methods of communication (whether flyers, social media posts, or other forms) to make them more appealing for people in the target audience (Manser Payne 2017). Participants should also be able to understand what is being asked of them, and why they should contribute. An obvious, but important, observation was that people very rarely do things that they don't want to do, and this thinking needs to be built into our development of citizen science projects to make sure people feel that they want to, and maybe even need to, take part (Liu 2017). As people progress through a project, friction between stages should be minimised. For mass participation projects, it should be as easy as possible (considering time, effort, and cost) to participate at each stage. In some projects, it is not possible to eliminate friction between stages (e.g., when training is required to collect high-quality data), and so communication about this needs to be clear; it could even be presented as a direct benefit of participation.

We also learned that data on people is central to modern marketing (Kotler 2017), although citizen science practitioners always need to be mindful of any legislation and regulations that govern the use of personal data, as well as the ethical use of such data (Christine and Thinyane 2021). This was an important topic of great concern to many attendees, but detailed discussion was beyond the scope of the meeting. Marketers build Customer Relationship Management Databases (CRM) to collect and analyse customer data, identify new audiences, and manage communications (Harrison 2019). The general feeling from the chat threads was that larger citizen science projects could benefit from this tried-and-tested commercial model provided that ethical concerns regarding the use of data could be addressed. 
Once people have initially engaged, a focus of commercial marketing is to keep them engaged. Clear, positive communication is key to enhancing retention, and the lesson for citizen science was that people need to be directed to findings (publications, website, blogs, Social Media posts), and that communication should come in a personalised way, if possible. It is also crucial in commercial marketing and brand development to update people regularly (little and often), and not to lose momentum. Social media platforms offer a potentially effective solution for ongoing engagement of the public in citizen science (Regenberg 2019), but it can be daunting for the uninitiated. As well as engagement, social media mining can also provide useful subsequent ecological data and insights (e.g., Hart et al. 2018b). Companies use applications like Hootsuite and SproutSocial to manage social media posts, to interact with consumers, and to share success stories across multiple social media platforms, and attendees felt that they would benefit from this professional approach to communications.

\section{ADDRESSING UNEVENNESS IN PARTICIPATION THROUGH TAILORED APPROACHES}

Citizen science participation is currently unevenly distributed between different sectors of society, limiting the social value citizen science has the potential to deliver (Brouwer and Hessels 2019) and perhaps also having implications for the data that are generated (Purcell et al. 2012). Analyses of the demographics of participants in environmental citizen science projects that come primarily from Europe and North America show that participants are predominantly from white ethnic groups (Wright et al. 2015; Merenlender et al. 2016; Domroese and Johnson 2017), and are highly educated (Evans et al. 2005; Trumbull et al. 2000; Mac Domhnaill et al. 2020), affluent (Hobbs and White 2012; Overdevest et al. 2004), and middle aged or older (Domroese and Johnson 2017; Crall et al. 2013), a pattern that holds across citizen science more broadly (NASEM 2018).

To consider participation more formally, Pateman presented research that explored patterns of participation in more detail, looking at how different demographic characteristics interact with each other to affect participation (Pateman et al. 2021). As an example, people who identify as being from minority ethnic groups are even more unlikely to participate in citizen science if they are also female or middle aged or older. Once again, there was an emphasis on the need for better knowledge of participants, including understanding how the demographics of participants vary (for example, between type of project [e.g., collaborative or co-created] and roles or levels of responsibility within projects) and understanding more about the quality of participant experience. This is important because understanding the complexities of the demographics of participants is the starting point for developing strategies for widening engagement (West et al. 2021). The need for more research into the barriers different groups face and how these can be overcome was also emphasised, along with the effect of recruitment strategies including targeted engagement through community leaders (Brouwer and Hessels 2019). Linking back to earlier themes of the meeting, it was noted that participant motivations are important: People are more likely to participate in projects that appeal to their motivations (Shirk et al. 2012), and are more likely to stay involved and report better experiences in projects that match their motivations (Alender 2016). The value of taking this tailored approach was also a primary message from the section on marketing. Insights gained from applying a commercial marketing approach to recruitment and retention could also be used to increase the diversity of participants, to extend the reach of a project, and to impact the potential benefits of participation.

\section{WIDENING PARTICIPATION THROUGH PLACE, COMMUNITY, AND AMPLIFIERS}

A powerful method for widening participation is to focus on community approaches, and an effective approach to helping communities find relevance in citizen science projects is identifying practical applications of science in everyday life, sometimes termed "scientizing" (Clegg and Kolodner 2014). Clegg shared her experiences of scientizing in the Science Everywhere project. Focusing on helping youth in resource-constrained communities connect to STEM (science, technology, engineering, and mathematics) learning across home, school, and after-school/community contexts, the project team designed and situated a social media mobile app, large-screen displays, and communitybased programs for youth (with strong support from parents and community volunteers) to engage in liferelevant science experiences in two communities in the USA.

In one example from Science Everywhere, an outreach pastor at the local church in a mid-eastern USA neighbourhood was motivated to participate by relationships in the community. He worked with young people as they engaged in citizen science by investigating the water quality in the stream that ran behind their church and by making suggestions for storm water management practices to improve the water quality in the community. While not initially interested in science, the pastor, in his 
role as steward of the church facility, partnered with researchers in Science Everywhere and a local watershed society to plan and implement the development of a rain garden at the church. Citizen science therefore played a role in this grand alignment of the pastor's goals in bringing the community together, the church's need as a landowner to manage stormwater runoff, the watershed society's goal to protect and conserve rivers, and the scientists' goal to enhance STEM engagement. It was a powerful example to show attendees how starting with such community-facing goals and linking to a local sense of place has the potential to facilitate more sustained involvement of community members, particularly those currently underrepresented in citizen science.

\section{INCREASING ENGAGEMENT THROUGH CLEARER LANGUAGE AND FRAMING}

Working out how to scientize people's lives and how to engage them in citizen science projects can mean taking a step back to view the project, and the science underpinning it, with the lens that participants might use. Attendees learned from Underhill that it matters what words are used when speaking about projects: Words provoke feelings and associations (positive and negative), and different groups may respond differently. In science, terms are often used that do not have a shared or common understanding (e.g., the word "theory" is often used as an everyday synonym for "speculation" or "conjecture," but in science means a set of accepted ideas), or have no meaning to most people (jargon) (Bullock et al. 2019). A common practice for scientists is to try to explain terms that are used, but a word can vary depending on a person's frame of reference. Meeting participants were advised that when developing communication for citizen science, the best and simplest way to improve our communication is to spend time talking to non-scientists, friends, and family outside our specialist bubbles, as well as members of the target audience, testing communications on them. The golden rule is to truly listen to their response. If the person does not understand what was meant, then it is the communication that needs to change, not the listener's understanding.

\section{DEVELOPING THE USER EXPERIENCE FOR GREATER ENGAGEMENT AND RETENTION}

Most citizen science projects make use of digital portals for data collection (smartphone apps or websites), but if these do not engage and inspire, then participants may decide not to continue. This leads to consideration of the user experience (UX) - the presentation, design, and usability of digital technology. Participants learned that there is great investment in UX in the commercial world to create highly usable apps designed to compete and to make money. Through discussions, it became clear that a well-thoughtout design and flow in digital tools for citizen science would likely increase engagement, positive experience, and reach, whereas poor user experience could discourage even highly motivated people from participating.

One of the challenges for citizen science practitioners is how to access ways of developing UX. Prior to actually designing anything, it is important to generate a vision for the citizen science project or product. There are many ways to achieve this, but the tool that participants were introduced to was the Lean UX Canvas (jeffgothelf.com/blog/ leanuxcanvas). This allows practitioners to reflect on the design problem, outcomes, users, benefits, and design hypotheses. One of the key mantras of UX Design is that "you are not your user," so yet again the clear message to the meeting was that understanding the potential participants is vital; this could be accomplished via user research (as in commercial marketing) and/or co-design (as in collaborative citizen science). With insight on participants and a vision for the project, it is then possible to start developing design ideas. The best ideas can be worked up into an interactive prototype using tools such as Figma (www.figma.com) or AdobeXD (www.adobe.com/uk/ products/xd.html), and these can be used to remotely test design ideas with users prior to investing in information technology (IT) development. If a prototype is going to fail, this approach allows it to fail early and cheaply, saving time and money in the long run.

\section{CONCLUSIONS}

Overall, while there is a lot of experience and learning through evaluation within the citizen science community, this meeting demonstrated the wealth of additional experience from outside of our community of practice, and how we can learn from best practice in other customerfacing sectors. The key message that emerged was how important is it to have a clear understanding of participants and their motivations, their relationships with place and community, and their understanding of language and framing. This is especially true for projects that require a large uptake for success, but remains relevant for smallscale and co-created projects because, even for these, there is need for effective outreach, engagement, and consideration of participant retention. From the very start of a citizen science project, the framing, language, and 
potential outcomes for participants need to be considered, regardless of the type of project being developed. Ideas from marketing and UX design can be integrated, but knowledge of the potential participants is vital. We need, but often lack, knowledge about the people that take part in projects and those who do not, and the reasons for their involvement or non-involvement. While some citizen science practitioners may feel uneasy about some of the more commercial approaches brought to the fore in this meeting, there is clearly the opportunity for reflection and learning from best practice elsewhere.

\section{ACKNOWLEDGEMENTS}

We thank the British Ecological Society who supported this meeting through their Citizen Science Special Interest Group. MJOP was supported by the Terrestrial Surveillance Development and Analysis partnership of the UK Centre for Ecology \& Hydrology, British Trust for Ornithology and the Joint Nature Conservation Committee and by the Natural Environment Research Council award number NE/ R016429/1 as part of the UK-SCAPE programme delivering National Capability.

\section{COMPETING INTERESTS}

The authors have no competing interests to declare.

\section{AUTHOR CONTRIBUTIONS}

AGH and MJOP led on planning, AGH led on writing, assisted by all authors.

\section{AUTHOR AFFILIATIONS}

Adam G. Hart (D) orcid.org/0000-0002-4795-9986

University of Gloucestershire, GB

David Adcock

Ten4 Design, GB

\section{Matthew Barr}

University of Gloucestershire, GB

Stuart Church (D) orcid.org/0000-0002-2654-9611

Pure Usability, GB

Tamara Clegg (D) orcid.org/0000-0001-6558-6944

University of Maryland, US

Samuel Copland (D) orcid.org/0000-0002-7469-8320 University of Gloucestershire, GB

Kris De Meyer (D) orcid.org/0000-0003-4351-8937

University College London, GB

\section{Ria Dunkley}

University of Glasgow, GB

Rachel M. Pateman (D) orcid.org/0000-0002-2260-170X

University of York, GB

Ralph Underhill

Framing Matters, GB

Kayleigh Wyles (D) orcid.org/0000-0003-3205-9595

University of Plymouth, GB

Michaeol J. O. Pocock (D) orcid.org/0000-0003-4375-0445

UK Centre for Ecology and Hydrology, GB

\section{REFERENCES}

Albarracin, D and Wyer, RS, Jr. 2000. The cognitive impact of past behavior: influences on beliefs, attitudes, and future behavioral decisions. Journal of Personality and Social Psychology, 79: 5-22. DOI: https://doi.org/10.1037/00223514.79.1.5

Alender, B. 2016. Understanding volunteer motivations to participate in citizen science projects: a deeper look at water quality monitoring. Jcom-Journal of Science Communication, 15: A04. DOI: https://doi.org/10.22323/2.15030204

Bonney, R, Phillips, TB, Ballard, HL and Enck, JW. 2016. Can citizen science enhance public understanding of science? Public Understanding of Science, 25: 2-16. DOI: https://doi.org/10.1177/0963662515607406

Brossard, D, Lewenstein, B and Bonney, R. 2005. Scientific knowledge and attitude change: The impact of a citizen science project. International Journal of Science Education, 27: 1099-1121. DOI: https://doi. org/10.1080/09500690500069483

Brouwer, S and Hessels, LK. 2019. Increasing research impact with citizen science: The influence of recruitment strategies on sample diversity. Public Understanding of Science, 28: 606-621. DOI: https://doi.org/10.1177/0963662519840934

Bullock, OM, Colón Amill, D, Shulman, HC and Dixon,

GN. 2019. Jargon as a barrier to effective science communication: Evidence from metacognition. Public Understanding of Science, 28: 845-853. DOI: https://doi. org/10.1177/0963662519865687

Christine, DI and Thinyane, M. 2021. Citizen science as a databased practice: A consideration of data justice. Patterns, 2: 100224. DOI: https://doi.org/10.1016/j.patter.2021.100224

Clegg, T and Kolodner, J. 2014. Scientizing and cooking: Helping middleschool learners develop scientific dispositions. Science Education, 98: 36-63. DOI: https://doi.org/10.1002/sce.21083

Cooper, CB, Hawn, CL, Larson, LR, Parrish, JK, Bowser, G, Cavalier, D, Dunn, RR, Haklay, M, Gupta, KK, Jelks, NTO and Johnson, VA. 2021. Inclusion in citizen science: The conundrum of rebranding. Science, 372 (6549): 1386-1388. DOI: https://doi.org/10.1126/science.abi6487 
Crall, AW, Jordan, R, Holfelder, K, Newman, GJ, Graham, J and Waller, DM. 2013. The impacts of an invasive species citizen science training program on participant attitudes, behavior, and science literacy. Public Understanding of Science, 22: 745-764. DOI: https://doi.org/10.1177/0963662511434894

De Meyer, K, Coren, E, McCaffrey, MS and Slean, C. 2020. Transforming the stories we tell about climate change: from 'issue' to 'action'. Environmental Research Letters, 16: 1. DOI: https://doi.org/10.1088/1748-9326/abcd5a

Dickinson, JL, Shirk, J, Bonter, D, Bonney, R, Crain, R, Martin, J, Phillips, T and Purcell, K. 2012. The current state of citizen science as a tool for ecological research and public engagement. Frontiers in Ecology and the Environment, 10: 291-297. DOI: https://doi.org/10.1890/110236

Domroese, MC and Johnson, EA. 2017. Why watch bees? Motivations of citizen science volunteers in the Great Pollinator Project. Biological Conservation, 208: 40-47. DOI: https://doi.org/10.1016/j.biocon.2016.08.020

Dunkley, RA. 2017. The Role of Citizen Science in Environmental Education: A Critical Exploration of the Environmental Citizen Science Experience. In Analyzing the Role of Citizen Science in Modern Research, 213-230. IGI Global. DOI: https://doi. org/10.4018/978-1-5225-0962-2.ch010

Dunkley, RA. 2018. Space-timescapes as ecopedagogy. The Journal of Environmental Education, 49: 117-129. DOI: https://doi.org/10.1080/00958964.2017.1417223

Dunkley, RA. 2019. Monitoring ecological change in UK woodlands and rivers: An exploration of the relational geographies of citizen science. Transactions of the Institute of British Geographers, 44: 16-31. DOI: https://doi.org/10.1111/ tran.12258

Evans, C, Abrams, E, Reitsma, R, Roux, K, Salmonsen, L and Marra, PP. 2005. The Neighborhood Nestwatch program: Participant outcomes of a citizen-science ecological research project. Conservation Biology, 19: 589-594. DOI: https://doi. org/10.1111/j.1523-1739.2005.00s01.x

Geoghegan, H, Dyke, A, Pateman, R, West, S and Everett, G. 2016. Understanding motivations for citizen science. Final report on behalf of UKEOF. University of Reading, Stockholm Environment Institute (University of York) and University of the West of England.

Hart, AG, Carpenter, WS, Hlustik-Smith, E, Reed, M and Goodenough, AE. 2018b. Testing the potential of Twitter mining methods for data acquisition: Evaluating novel opportunities for ecological research in multiple taxa. Methods in Ecology and Evolution, 9: 2194-2205. DOI: https://doi.org/10.1111/2041-210X.13063

Hart, AG, Hesselberg, T, Nesbit, R and Goodenough, AE. 2018a. The spatial distribution and environmental triggers of ant mating flights: using citizenscience data to reveal national patterns. Ecography, 41: 877-888. DOI: https://doi. org/10.1111/ecog.03140
Hobbs, SJ and White, PCL. 2012. Motivations and barriers in relation to community participation in biodiversity recording. Journal for Nature Conservation, 20: 364-373. DOI: https:// doi.org/10.1016/j.jnc.2012.08.002

Kotler, P and Armstrong, G. 2020. Principles of marketing (Eighteenth edition, Global). Pearson Education.

Mac Domhnaill, C, Lyons, S and Nolan, A. 2020. The citizens in citizen science: demographic, socioeconomic, and health characteristics of biodiversity recorders in Ireland. Citizen Science: Theory and Practice, 5: 16. DOI: https://doi. org/10.5334/cstp.283

Martin, VY. 2017. Citizen Science as a Means for Increasing Public Engagement in Science: Presumption or Possibility? Science Communication, 39: 142-168. DOI: https://doi. org/10.1177/1075547017696165

Merenlender, AM, Crall, AW, Drill, S, Prysby, M and Ballard, $\mathbf{H}$. 2016. Evaluating environmental education, citizen science, and stewardship through naturalist programs. Conservation Biology, 30: 1255-1265. DOI: https://doi.org/10.1111/cobi.12737

NASEM 2018: National Academies of Science, Engineering and Medicine. 2018. Learning Through Citizen Science: Enhancing Opportunities by Design. Washington, DC, USA: The National Academies Press.

Newman, G, Chandler, M, Clyde, M, McGreavy, B, Haklay, M, Ballard, H, Gray, S, Scarpino, R, Hauptfeld, R, Mellor, D and Gallo, J. 2017. Leveraging the power of place in citizen science for effective conservation decision making. Biological Conservation, 208: 55-64. DOI: https://doi.org/10.1016/j. biocon.2016.07.019

Osei-Frimpong, K. 2019. Understanding consumer motivations in online social brand engagement participation. International Journal of Retail and Distribution Management, 47: 511-529. DOI: https://doi.org/10.1108/IJRDM-08-2018-0151

Overdevest, C, Orr, CH and Stepenuck, K. 2004. Volunteer stream monitoring and local participation in natural resource issues. Research in Human Ecology, 11: 177-185.

Pateman, RM, Dyke, A and West, SE. 2021. The Diversity of Participants in Citizen Science. Citizen Science. Theory and Practice, 6: 9. DOI: https://doi.org/10.5334/cstp.369

Pocock, MJO, Tweddle, JC, Savage, J, Robinson, LD and Roy, HE. 2017. The diversity and evolution of ecological and environmental citizen science. PLOS ONE, 12: e0172579. DOI: https://doi.org/10.1371/journal.pone.0172579

Purcell, K, Garibay, C and Dickinson, JL. 2012. A Gateway to Science for All: Celebrate Urban Birds: Public Participation in Environmental Research. In Citizen Science, Dickinson, $\mathrm{JL}$ and Bonney, R (eds.). Cornell University Press Comstock Publishing Associates. DOI: https://doi.org/10.7591/ cornell/9780801449116.003.0014

Regenberg, A. 2019. Science and social media. Stem Cells Translational Medicine, 8: 1226-1229. DOI: https://doi. org/10.1002/sctm.19-0066 
Robinson, LD, Cawthray, JL, West, SE, Bonn, A and Ansine, J. 2018. Ten principles of citizen science. In Citizen science: Innovation in open science, society and policy, 27-40. UCL Press. DOI: https://doi.org/10.2307/j.ctv550cf2.9

Shirk, JL, Ballard, HL, Wilderman, CC, Phillips, T, Wiggins, A, Jordan, R, McCallie, E, Minarchek, M, Lewenstein, BV, Krasny, ME, et al. 2012. Public Participation in Scientific Research: a Framework for Deliberate Design. Ecology and Society, 17: 29. DOI: https://doi.org/10.5751/ES-04705170229

Sumner, S, Bevan, P, Hart, AG and Isaac, NJ. 2019. Mapping species distributions in 2 weeks using citizen science. Insect Conservation and Diversity, 12: 382-388. DOI: https://doi. org/10.1111/icad.12345

Theobald, EJ, Ettinger, AK, Burgess, HK, DeBey, LB, Schmidt, NR, Froehlich, HE, Wagner, C, HilleRisLambers, J, Tewksbury, J, Harsch, MA and Parrish, JK. 2015. Global change and local solutions: Tapping the unrealized potential of citizen science for biodiversity research. Biological Conservation, 181: 236-244. DOI: https://doi.org/10.1016/j.biocon.2014.10.021

Trumbull, DJ, Bonney, R, Bascom, D and Cabral, A. 2000. Thinking scientifically during participation in a citizen-science project. Science Education, 84: 265-275. DOI: https://doi.org/10.1002/ (SICI)1098-237X(200003)84:2<265::AID-SCE7>3.0.CO;2-5

Tuan, YF. 1974. Topophilia. Englewood Cliffs, NJ: Prentice-Hall. Turrini, T, Dörler, D, Richter, A, Heigl, F and Bonn, A. 2018. The threefold potential of environmental citizen scienceGenerating knowledge, creating learning opportunities and enabling civic participation. Biological Conservation, 225:

176-186. DOI: https://doi.org/10.1016/j.biocon.2018.03.024

West, S and Pateman, R. 2016. Recruiting and retaining participants in citizen science: What can be learned from the volunteering literature? Citizen Science: Theory and Practice, 1(2). DOI: https://doi.org/10.5334/cstp.8

West, SE, Pateman, RM and Dyke, A. 2021. Variations in the Motivations of Environmental Citizen Scientists. Citizen Science: Theory and Practice, 6: 1-8. DOI: https://doi. org/10.5334/cstp.370

Wheeler, BW, White, M, Stahl-Timmins, $\mathbf{W}$ and Depledge, MH. 2012. Does living by the coast improve health and wellbeing? Health and Place, 18: 1198-1201. DOI: https://doi. org/10.1016/j.healthplace.2012.06.015

White, MP, Pahl, S, Ashbullby, K, Herbert, S and Depledge, MH. 2013. Feelings of restoration from recent nature visits. Journal of Environmental Psychology, 35: 40-51. DOI: https:// doi.org/10.1016/j.jenvp.2013.04.002

Wright, DR, Underhill, LG, Keene, M and Knight, AT. 2015. Understanding the motivations and satisfactions of volunteers to improve the effectiveness of citizen science programs. Society and Natural Resources, 28: 1013-1029. DOI: https://doi.org/10.1080/08941920.2015.1054976

Wyles, KJ, Pahl, S, Holland, M and Thompson, RC. 2017. Can beach cleans do more than clean up litter? Comparing beach cleans to other coastal activities. Environment and Behavior, 49: 509-535. DOI: https://doi. org/10.1177/0013916516649412

TO CITE THIS ARTICLE:

Hart, AG, Adcock, D, Barr, M, Church, S, Clegg, T, Copland, S, De Meyer, K, Dunkley, R, Pateman, RM, Underhill, R, Wyles, K and Pocock, MJO. 2022. Understanding Engagement, Marketing, and Motivation to Benefit Recruitment and Retention in Citizen Science. Citizen Science: Theory and Practice, 7(1): 5, pp. 1-9. DOI: https://doi.org/10.5334/cstp.436

Submitted: 20 April $2021 \quad$ Accepted: 13 January 2022 Published: 24 February 2022

\section{COPYRIGHT:}

(C) 2022 The Author(s). This is an open-access article distributed under the terms of the Creative Commons Attribution 4.0 International License (CC-BY 4.0), which permits unrestricted use, distribution, and reproduction in any medium, provided the original author and source are credited. See http://creativecommons.org/licenses/by/4.0/.

Citizen Science: Theory and Practice is a peer-reviewed open access journal published by Ubiquity Press.

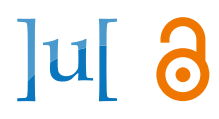

